\title{
Maintenance of submersible pumps in the septic tanks: ergonomic and biological risks to the worker
}

\author{
Suzi Mariño $0^{\mathrm{a}, *}$ and Alex Figueiredo ${ }^{\mathrm{b}}$ \\ ${ }^{a}$ Department of Design, State and Federal University of Bahia, Rua Teixeira de Barros, 800/607-B, Brotas, CEP \\ 40.279-080, Salvador, Bahia, Brazil \\ ${ }^{\mathrm{b}}$ Department of Production Engineering, Faculty of Science and Technologists - AREA 1, Rua Teixeira de \\ Barros, 800/607-B, Brotas, CEP 40.279-080, Salvador, Bahia, Brazil
}

\begin{abstract}
In this study was observed the maintenance task of submersible pumps septic tanks installed in industrial bathrooms. This maintenance activity operators are exposed to various biological and ergonomic risks. This type of activity requires its great physical performers who are also subject to contact with human waste in the form of liquids, gases and solids. Besides the problems mentioned, are still exposed to high temperatures that can cause diseases such as hyperthermia or heatstroke. These aspects were observed using the ergonomic assessment methodology in order to suggest improvements that are reflected in productivity and employee satisfaction.
\end{abstract}

Keywords: ergonomic risk, biological risks, equipment maintenance

\section{Introduction}

Ergonomics is a discipline related to understanding the interactions between humans and other elements or systems, and application of theories, principles, data and methods for projects to improve the well being and overall system performance, according to the [4].

The services provided by a company are to carry out building maintenance within industries, and one of the services performed is the maintenance of submersible pumps septic tanks installed in bathrooms in production areas. Ergonomics has tools that allow maximizing the comfort and satisfaction with the work of man, identifying dysfunctions and diseases associated with implementation of tasks, ensuring safety and minimizing the work arising from physical and psychological burdens of the workers.

In this study was observed the task of maintenance of submersible pumps septic tank installed in bathrooms from industrial ergonomic approach.
In this activity the maintenance are exposed to various biological and ergonomic risks. This type of activity requires of its great physical performers who are also subject to contact with human waste in the form of liquids, gases and solids. Besides the problems mentioned, still has thermal comfort. As [9], exposure to high temperatures can cause diseases such as hyperthermia or heatstroke.

In recent years, there is a growing concern to establish a smooth adaptation of the relationship between human beings and their work, because for the accomplishment of maintenance activity at the pumps, the maintenance are exposed to various biological, ergonomic and labor accident. This type of activity is a service that requires operators of their great physical strength which are subject to contact with human waste in the workplace in the form of liquids, gases and solids. Concern about thermal comfort is also evident and maintenance. As [9], the exposure of workers in performing tasks at high tem-

*Corresponding author. E-mail: suzimarino@gmail.com. 
peratures can cause diseases such as hyperthermia or hospitalization.

To decrease these risks are some safety procedures required the use of Personal Protective Equipment (PPE). Its use brings greater security and peace of mind to workers: half-face masks, waterproof boots, and latex gloves, goggles and overalls tayvek waterproof. To allow the operators to perform this activity, should be concerned with poor posture, improper temperatures, infectious bacteria and viruses. In addition to the considerations on the conditions of work already highlighted, [13] consider that the worker's ability to perform the work is also a factor to be treated carefully. Some aspects are directly related to it, such as biological and functional aspects, which refer to biomechanics, external aspects that are the polluters of the environment.

These aspects were observed and analyzed during the execution of maintenance activities by using the methodology for assessing ergonomic proposed by [1], in order to suggest improvements that are reflected in productivity and employee satisfaction.

\subsection{Submersible pump}

The submersible pump is a type of pump with a sealed device (Shielded Motor), which operates by pressing, instead of pull, the liquid during the pumping process. It is able to work this way because, as the name suggests, the pump is fully submerged in the liquid being pumped. This allows it to be downloaded in a deep hole without need for pumping occurring problems such as pump cavitations, which can damage the moving parts through the development of vapor bubbles. The submersible pumps are used in a wide variety of applications from commercial and industrial use, are for various types of applications such as septic tank, water tank and is a great ally in the depletion of clean and dirty water. Made from strong materials and are also known as drain pump or frog.

The main advantage of this pump is that it avoids a problem associated with the difference in elevation between the pump and the liquid surface. One of the principles of operation is connecting the pump to a hose or tube guide so that the pump does not rotate when fired in a pit or pit, playing well for channeling the fluid air.

While it is easy to install equipment, it is recommended to be installed by qualified persons prepared and, following the recommendations of manufacturers and of the regulation [5] even within the safety regulations, this does not lessen the risk of accidents or damage to equipment.

Despite this pump system be better than the pump jet, for some applications it is not indicated, for example, the septic system is that when the need for maintenance, it is hoisted and maintenance have direct contact with human waste, endangering the health of workers who have to perform this type of task. In this case it is recommended to use another type of pump.

\subsection{Ergonomics risks}

The [6] mentions that all risk is likely to damage possible within a period of time or number of operating cycles. The occurrence of a damaging event occurs, is on the existence or preventative measures to ensure compliance of environmental conditions or performance of procedures respecting Biosafety rules.

According to the author, ergonomics is applied in different industrial levels and aims to achieve practical security and satisfaction, and especially the welfare of workers in their relationship with production systems, thereby reducing the number of cases of occupational diseases. There are some guidelines for dealing with [6] on the procedures related to ergonomics, to transform the working environment to employees.

This rule also emphasizes that the rule dictates the procedures to be applied in establishments where workers performing any professional activity, especially those that excite survey, individual transport and unloading of materials, distinguishing cases in which the individual is female, smaller and older people. In these cases special care must be taken. Table 1 shows the relationship of weight and limits for their lifting.

Ergonomic risks are considered, strict control of productivity, weight lifting, prolonged working hours and other things. The risks related to ergonomics has been one of the biggest reasons for complaints from workers in the workplace, is not the simplest task to quantify factors such as satisfaction, wellbeing, tiredness, pain etc., in an organization.

It could be any factor that might interfere with the psychophysiological characteristics of the worker, causing discomfort or affecting your health. A poor posture can cause the worker's back pain, pain, fatigue or stiffness in the lumbar region.

These ergonomic risks lead workers to a series of disorders such as: physiological, psychological and economic. Where not only affect the worker, but also his entire family. The maintenance workers submers- 
ible pumps are exposed to various types of ergonomic risk such as poor posture, biological contamination, risks of falls among others. The risks involved in this maintenance activity generate pro occupational diseases such as: back pain, diarrhea, tuberculosis etc.

\subsection{Biological risks}

According [3], it is known that fifty types of infections can be transmitted through different pathways involving human excreta. For purposes of [7] is considered biological risks the likelihood of occupational exposure to biological agents such as; organism, genetically modified or not, cell cultures, parasites and toxins, agents found in submersible pumps septic tank.

The dangerous biological agents are organized into four classes, in which the ascending order of the number indicates a greater danger. According to [2], the class "1" includes the agents of non-hazardous or danger that does not require minimum equipment and experienced professionals for its manipulation. The class "2" is represented by common agents of potential danger, includes all the agents that can cause disease with varying degrees of severity. The class "3" includes pathogens that require special restrictive conditions; these conditions include controlled access facilities, negative pressure in the workplace. In class "4" are framed agents that require closer restrictive conditions, in extreme danger or because they can cause epidemics.

The biological risk may be high, because the noncompliance is very high although the measures of prevention are well defined. Some operators aware of the risks involved in the task ultimately commit unsafe acts, putting their health and physical integrity in danger. The task of maintaining the submersible pumps in septic tanks is one of the activities with a high risk of biological contamination through contact with the maintenance of human waste.

The existing biological risks in the workplace and are often unknown or even ignored, mainly due to lack of knowledge of employers and workers or by the specific training of workers. What the other hand is understandable, since the intensity with which affect workers is much lower than the chemical and physical risks, but no less important. Thus, its importance can not be neglected.

On the desktop analyzed workers are exposed to various types of contamination, even with some measures to prevent the risks can not be eliminated entirely. The biological risks are being made primarily from exposure to microorganisms present in hu- man waste or waste and other animal species. When using the process of maintenance of submersible pumps in septic tanks or waste treatment these organisms can be dispersed in air represents a source of contamination. The main microorganisms are fungi, bacteria and viruses that can cause acute or chronic diseases. Among the diseases prevalent acute infectious diarrheal diseases, respiratory and liver. The Chronicles are represented mainly by bronchial asthma and allergic alveolitis.

These types of biological agents entering the human body through the digestive, respiratory, eye and skin, are responsible for some diseases, which can result in minor illnesses such as intestinal infections or the common cold, or more serious such as hepatitis, meningitis or AIDS (Acquired Immunodeficiency Syndrome). These organisms adapt better and reproduce more in dirty environments.

\section{Method}

The methodology used for this work was the Ergonomic Assessment [1], a post maintenance of submersible pumps in septic tanks, in proposing suggestions for improvement of the conditions found, focused on the concepts of man-machine system (SHM).

Thus, it is not intended to study the man alone, but rather its interaction with the environment, equipment and tools that involves the execution of the task on the job.

In order to know the type of professional activity developed, was performed an observational study aiming to identify the dominant posture adopted while performing the activity, the effort required and the manner of execution of professional tasks. Through this study were observed temperature, odors, ventilation, distribution of the physical area, the use of protective equipment, how to do the work, the use of the equipment to do the work required and postures. It was also the object of study of the aseptic workstation maintenance and contact with human waste.

\section{Results}

In buildings where there is the possibility of disposing of waste via the sewers, septic tanks are built. These septic tanks work with submersible pumps that push the waste and send it to the air pipe of carbon 
steel that are connected to a sewage station, where it is done processing and analysis within specifications and is sent to their final destination.

The submersible pumps usually have problems because of its useful life and clogging of the valve caused by objects thrown in the toilets. As illustrated in Figures 1 - 11, operators remove the first valve, and then the cap is removed from notch to tie a rope on the tab of the pump to do the lifting and then perform the maintenance. In this task, they are exposed to odors, bacterial contamination, inadequate posture and risks of falling into the septic tanks.

When the submersible pumps have trouble, the septic tanks begins to overflow causing a nuisance to other sectors of industry because of the stench and the banning of the bathroom, resulting sometimes in threatening to halt production.

Besides the problems pointed out, the task is also complicated by the lack of proper ventilation and exhaust that is aggravated by the use of PPE recommended (tayvek veralls made of waterproof fabric).

\subsection{Categorization and taxonomy of the ergonomic problems of man-machine-system}

Biological problems: Lack of hygiene and asepsis, which allows the proliferation of pathogenic organisms (bacteria and viruses) fungi and other microorganisms. (Figures 1-6)

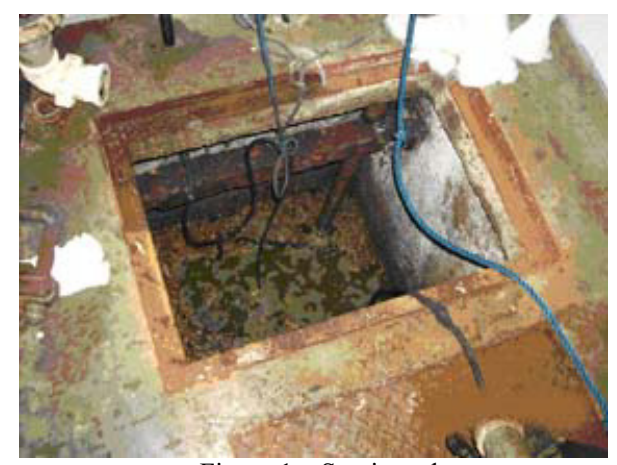

Figure 1 - Septic tanks.

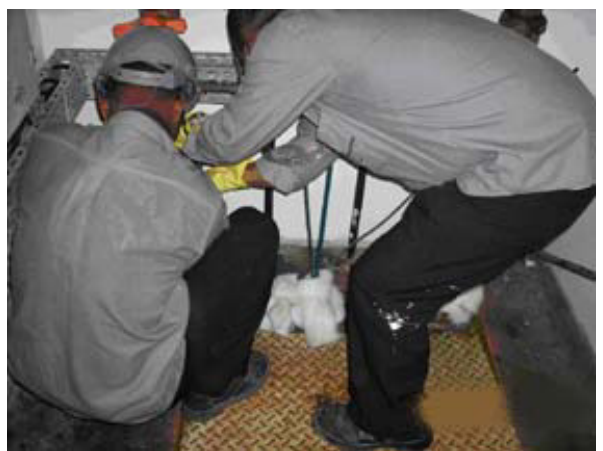

Figure 2 - Remove the check valve - Performing maintenance removal of the valve that provides that they be exposed to waste harmful to health such as bacteria. Exposing them to the ergonomic and biological risks such as back pain, tuberculosis, diarrhea

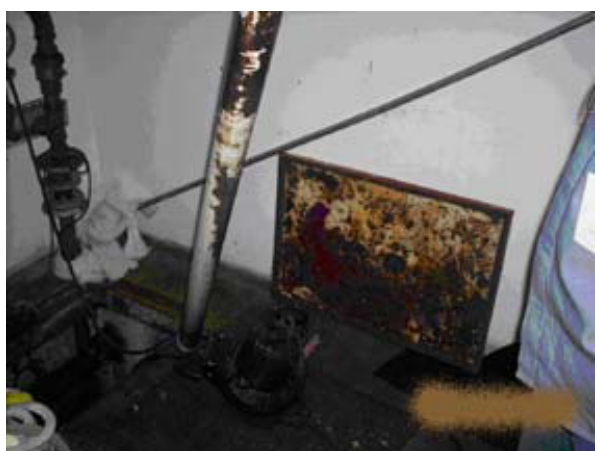

Figure 3 - House of submersible pump - The work environment is an unsafe condition providing maintenance to contamination by bacteria from of the dejections that are steeped on the cover of the tank and piping in which they have direct contact to the maintenance of submersible pump.

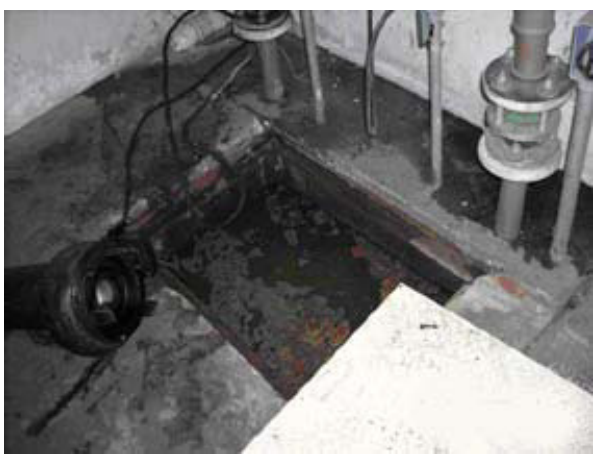

Figure 4 - Pump frog. 


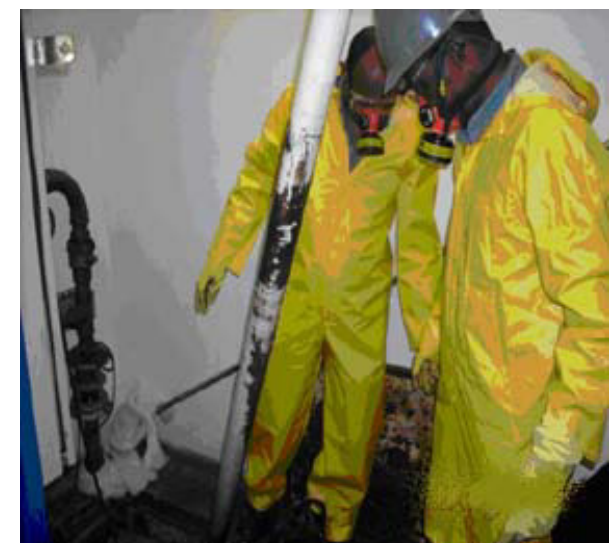

Figure 5 - Tubing infected of waste - For the task, the overall maintenance and use PPE Tayvec (waterproof fabric), half-face mask, PVC gloves, but even with the use of PPE they are exposed to biological and ergonomic risks.

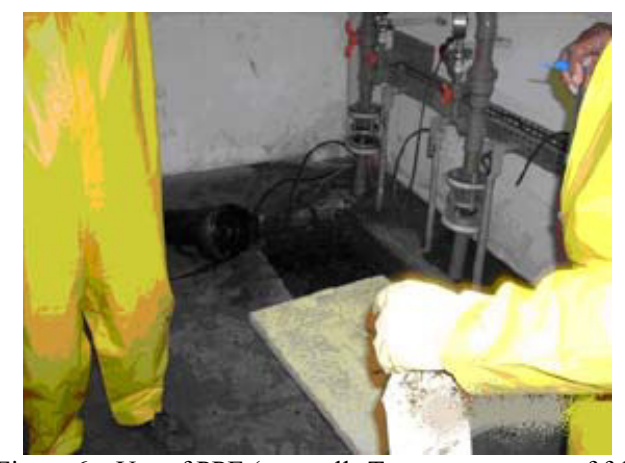

Figure 6 - Use of PPE (coveralls Tayvec - waterproof fabric) semi-facial mask, PVC gloves.

Interfacial problems: Postures injuriously wrap ational/ranges, with damage to the muscular and skeletal systems. Figures 7 - 11 show the operator adopting inadequate posture with trunk flexion with high load to service the pump.

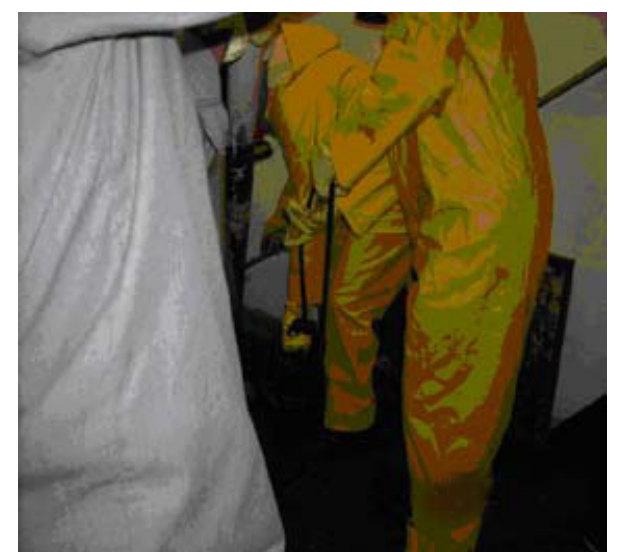

Figure 7 - For the implementation of the maintenance task adopts postures with flexion of the trunk with the front elevation of the load for lifting submersible pump, causing low back pain, causing low back pain, loss of different level.

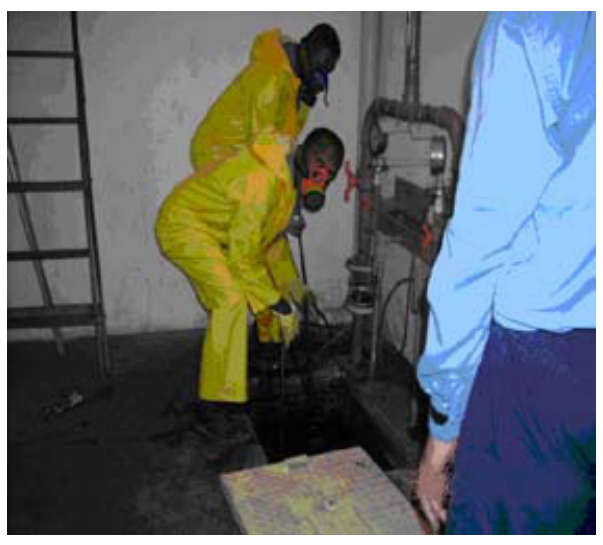

Figure 8 - Sequence of the task of lifting the pump in the tank.

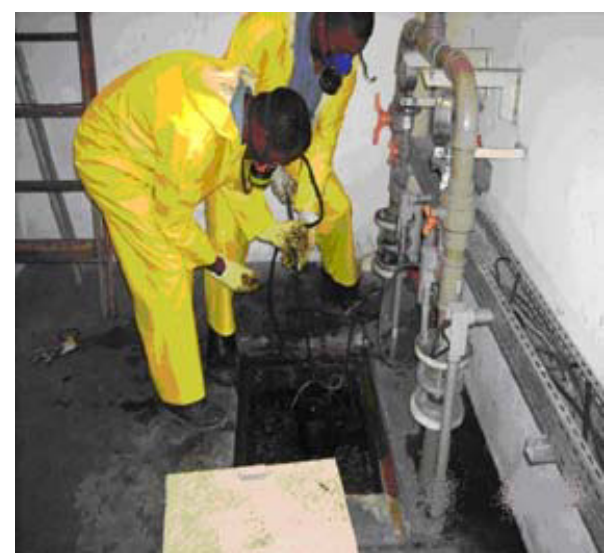

Figure 9 - Sequence of the task of lifting the pump in the tank.

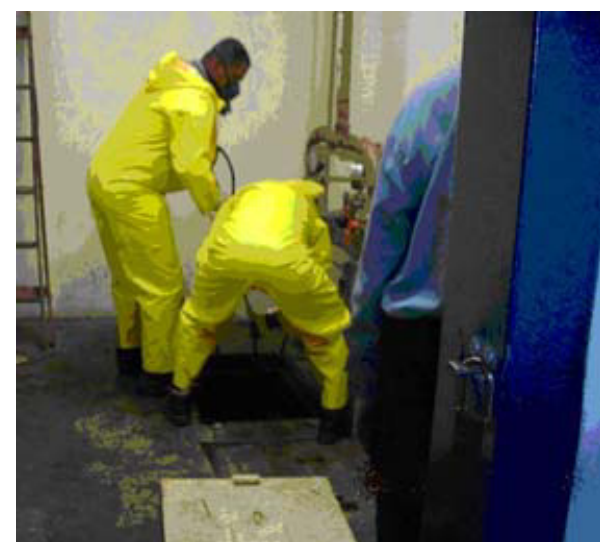

Figure 10 - Sequence of the task of lifting the pump in the tank. 


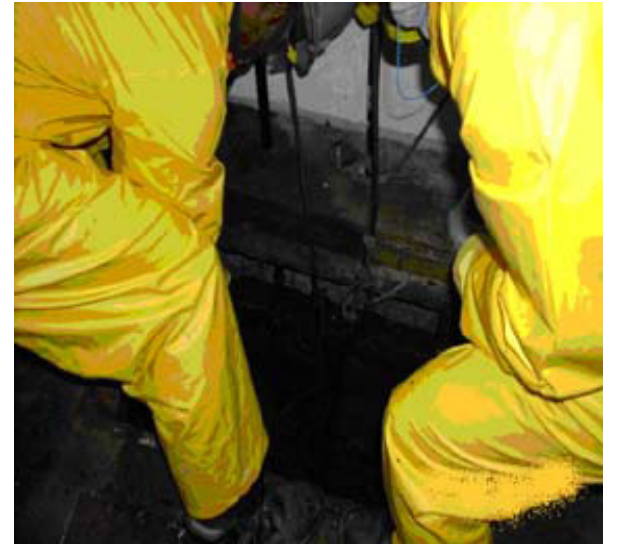

Figure 11 - Sequence of the task of lifting the pump in the tank.

\section{Discussion}

According to Ergonomic Assessment presented, it can be suggested as the focus of observation in the permanence of Diagnosis maintenance of biological risk exposure, with direct contact with human waste to the task. Systematic observation, therefore, should focus on getting maintenance of poor posture with the trunk flexed to the lift pump to service the same, the preliminary suggestions for improvement given the main problems are:

- A rearrangement of plant by installing another bomb is seen as an initial measure to propose other solutions

- Installation of a support to put a pulley, thereby prevents the maintenance remain with the trunk flexed and decrease the weight of the pump;

- Install an exhaust fan to remove odors and have good ventilation;

- Installation of a pump that remains out of the septic tank, minimizing contact with the maintenance of human waste.

These recommendations are intended to give the employee a less harmful, without flexion of the trunk and no contact with human waste.

It is concluded that the ergonomic approach to the process of continuous improvement and their applicability to obtain comfort and quality of life, is an alternative that has been adopted by several organizations for its multidisciplinary character. It has the basic objective of the adaptation of working conditions, the characteristics of man in order to optimize their performance by assessing the physical, spatial, biological and behavioral. If there is a need to establish and motivate some changes, mainly of behavior, to achieve the desired results.

Used as objects of study in building maintenance industries, research has shown, based on observation, that during the activity, the maintenance are exposed to biological and ergonomic risks. Was confirmed that some health problems may arise due to bad working conditions, inadequate implementation of the activity, and physical environmental factors, reducing their ability to work, interfering with quality of service and especially the quality of life of workers.

Thus, the solutions proposed in this study were based, bibliographies studying ergonomics as a means to solve problems that directly influence the productivity, indicating some environmental factors, physical and posture, which can cause injury, occupational diseases and low income on the job. The goal of ergonomics is to provide maximum comfort, safety and quality of life for maintenance.

Therefore, it is concluded that the development of this research enabled the knowledge acquired through literature searches and technical visits, facilitated the visualization and understanding of problems and difficulties faced by the maintenance building to carry out the maintenance activity of submersible pumps within the health area of production in industries. Indicating, from the clear understanding of the real needs, the use of ergonomics to improve productivity, comfort, satisfaction and safety maintenance.

\section{References}

[1] A. Moraes, C. Mont'alvão, Ergonomia conceitos e aplicações, Rio de Janeiro: 2AB, 2010.

[2] A. N. Barborsa Filho, Gestão de segurança e ambiental. São Paulo: Atlas, 2009

[3] Abes Associação Brasileira de.Engenharia Sanitária e Ambiental. Política Nacional de Resíduos, Brasília, 2009.

[4] Associação Brasileira de Ergonomia. O que é a ergonomia. Disponível em: <http://www.abergo.org.br>. Acesso em: 4 out. 2010 .

[5] Associação Brasileira de Normas Técnicas, NR10: Segurança e Saúde no Trabalho. Rio de Janeiro, 2004.

[6] Associação Brasileira de Normas Técnicas. NR17: Segurança em Serviços e Instalações Elétricas, Rio de Janeiro, 2004.

[7] Associação Brasileira de Normas Técnicas. NR32: Segurança e Saúde no Trabalho em Serviços de Saúde e os Riscos Biológicos. Rio de Janeiro, 2006.

[8] E. Grandjean, K.H.E. Kroemer, Manual de Ergonomia: adaptando ao trabalho do homem. Porto Alegre: Bookman, 2005. 
[9] H. de A Couto, Ergonomia aplicada ao trabalho: manual técnico da máquina humana. Belo Horizonte: Ergo, 1995.

[10] I. Iida. Ergonomia: projeto e produção. São Paulo: Edgard Blücher, 2005

[11] Instituto Nacional de Seguridade. Norma Técnica LER. Brasília, 1993
[12] P. H Santos, Segurança e Saúde no Trabalho, São Paulo, 2009. Available at: http://www.paulo-henrique.com/site2/. Accessed agosto de 2009.

[13] P. Pequini, Intervenção ergonômica e suas implicações na produtividade e satisfação dos funcionários: estudo de caso de lavanderia industrial, Faculdade Área 1, 2007. 